\title{
Experimental Investigation and Mathematical Modelling of Heat Transfer Coefficient in Double Slope Solar Still
}

\author{
Raj Vardhan Patel1,2 - Anshul Yadav1,2 - Jerzy Winczek ${ }^{3 *}$ \\ ${ }^{1}$ Kamla Nehru Institute of Technology, India \\ ${ }^{2}$ CSIR-Central Salt and Marine Chemicals Research Institute, India \\ ${ }^{3}$ Czestochowa University of Technology, Poland
}

\begin{abstract}
In this study, a double slope solar still has been designed and fabricated with the help of locally available materials for the climatic condition of Sultanpur, India. The experimental study was performed to investigate the effect of basin water, wind velocity on the heat transfer coefficient (convective, evaporative, and radiative) and yield of solar still. A mathematical model is developed to understand the impact of wind velocity and basin water depth in the double slope solar still on the heat transfer coefficient. It was found that the convective heat transfer coefficient depends upon the water mass and the temperature of basin mass, and glass cover temperature. The maximum value of $h_{\mathrm{ew}}\left(55.05 \mathrm{~W} /\left(\mathrm{m}^{2} \mathrm{~K}\right)\right.$ and $\left.31.80 \mathrm{~W} /\left(\mathrm{m}^{2} \mathrm{~K}\right)\right)$ and $h_{\mathrm{cw}},\left(2.48 \mathrm{~W} /\left(\mathrm{m}^{2} \mathrm{~K}\right)\right.$ and $\left.2.38 \mathrm{~W} /\left(\mathrm{m}^{2} \mathrm{~K}\right)\right)$ found for depths of $2 \mathrm{~cm}$ and $5 \mathrm{~cm}$, respectively. The radiative heat transfer coefficient found to be a maximum of $8.31 \mathrm{~W} /\left(\mathrm{m}^{2} \mathrm{~K}\right)$ for $2 \mathrm{~cm}$ depth, and it increases as the condensation increases, because the glass surface temperature increases as vapour transfers its energy to the surface. On increasing the depth from $2 \mathrm{~cm}$ to $5 \mathrm{~cm}$, the yield from the solar still decreases by $25.45 \%$. The maximum yield of $2.5 \mathrm{l} / \mathrm{m}^{2} /$ day was found for a $2 \mathrm{~cm}$ water depth. The theoretical and experimental yield agreed with an error of $7.5 \%, 3.25 \%, 7.4 \%$, and $8.4 \%$ for water depths of $2 \mathrm{~cm}, 3 \mathrm{~cm}, 4 \mathrm{~cm}$, and $5 \mathrm{~cm}$, respectively. It was also found that the yield from the solar still increases as the wind speed increase because this leads the faster condensation at the glass surface.
\end{abstract}

Keywords: double slope solar still; solar energy; distillation; heat transfer coefficient

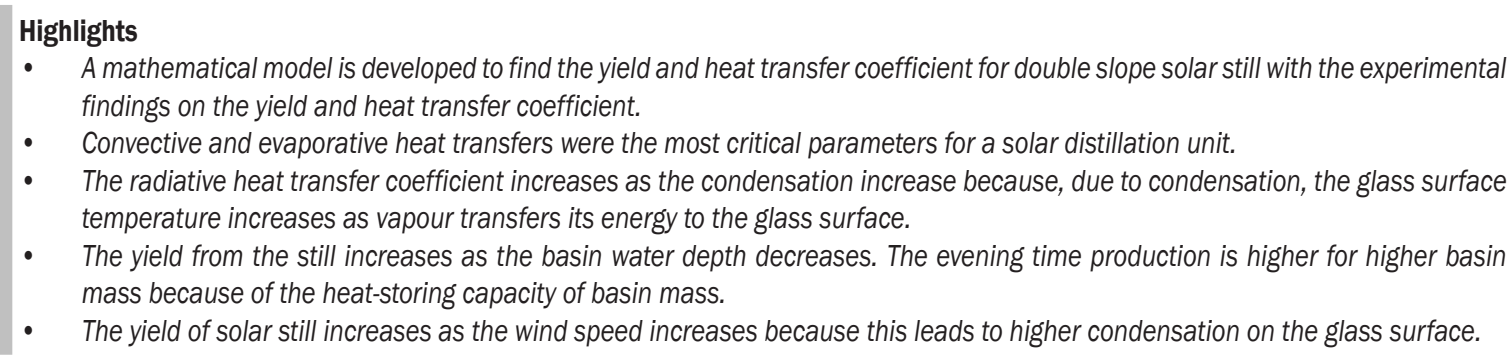

\section{INTRODUCTION}

Currently, energy and fresh water supplies are major challenges in remote areas. Only $1 \%$ of the total water available on the earth can be used for drinking. Current distillation methods use conventional fuel, which are a limited resource, and there is environmental pollution when such fuels are used to generate power. Solar stills are simple devices that can be used to produce potable water. They can be an effective solution for providing potable water in remote areas [1] and [2].

Solar stills are generally classified into two categories: active and passive [3] and [4]. Solar stills require only solar energy for their operation, which is freely available and eco-friendly, and work on the simple principle of evaporation and condensation. Solar distillation removes salts and other impurities [5] and [6]. It is used to produce potable or pure water for hospitals, laboratories, and commercial products [7] and [8].
The yield of a conventional solar still depends on the water mass in the basin. The effect of that water mass on the solar heat transfer still has been investigated by various researchers [9] to [11]. The studies concluded that as the mass of basin water increases, the yield from the system decreases. Dev et al. [9] investigated the inverted absorber single slope solar still, and found higher production of freshwater with $1 \mathrm{~cm}$ depth compared to $2 \mathrm{~cm}$ and $3 \mathrm{~cm}$ depths. Phadatare and Verma [10] studied water depth on the internal heat and mass transfer in the singlebasin double-slope solar still (DSSS). Tripathi and Tiwari [11] concluded that the yield from the system decreases as the mass of basin water increases. The experimental and analytical study performed by Feilizadeh et al. [12] reported that the production from the solar still increases as the water depth and distance between the water basin and the condensing cover is lower.

The radiative and convective heat transfer decrease as the water mass in the basin increases. 
The influence of wind on the production of solar stills was investigated by El-Sebaii [13] and [14], who determined that the increase in wind speed up to a critical value increases the yield of still. Higher wind speed decreases the yield because it decreases the basin temperature. An experiment conducted by Danish et al. [15] to enhance the performance of the solar still by using a vacuum pump and geothermal energy found that the increases in wind speed have a detrimental effect on the yield of solar still, because the increase in speed increases the heat loss from the basin water.

The production rate of solar stills is low; therefore, they cannot be used as a conventional water purifier. The yield from a solar desalination unit increased by incorporating phase change materials (PCM) [16] and [17] and nanofluids [18] and [19] to the basin water. Mathematical modelling has been as subject of some interest as it can optimize the efficiency and production by changing the different operational and geometrical parameters without losing its inherent feature of low cost; the main advantage associated with modelling analysis that much effort and cost can be minimized for carried out the experimentation [20] and [21]. Rahbar and Esfahani [22] proposed a numerical correlation to determine the productivity of a solar still by assuming the fixed water depth and glass temperature. The trends of water production are similar to the convective heat transfer coefficients. Madhlopa [23] modelled the radiative heat transfer inside a solar still with and without considering the view factor, and the numerical model with view factor involving provides better yield. Keshtkar et al. [24] proposed a novel transient model to calculate transient temperature and concentration distribution and also production from a solar still without specifying the water and glass surface temperatures as the boundary condition.

The production of a solar still is dependent on the rate of heat transfer in the solar still, basin water, and wind velocity (which provides glass cover cooling), and similar factors. The present study focuses on studying the variation of the heat transfer coefficient with basin water temperature and wind velocity for the acrylic solar still for the summer climatic condition of Sultanpur, India. The different heat transfer coefficient associated with DSSS is compared for different water depths, and the comparisons have been made for the orientations (i.e., east and west sides).

\section{EXPERIMENTS}

\subsection{Solar Distillation Unit}

The schematic diagram and the experimental setup of the DSSS are shown in Figs. 1 and 2, respectively. A passive DSSS is designed and fabricated to investigate the effect of climatic and operational parameters on a solar still for the summer climatic condition of Sultanpur (latitude: $26.2648^{\circ} \mathrm{N}$ and longitude: $82.0727^{\circ}$ E) Uttar Pradesh, India. The basin of the solar still is fabricated frin a black acrylic sheet of a thickness of $4 \mathrm{~mm}$. The basin size of the still is $1 \mathrm{~m} \times$ $1 \mathrm{~m} \times 0.1 \mathrm{~m}$. Plywood of $12 \mathrm{~mm}$ thickness is used for support and insulation of solar still basin in order to reduce the heat transfer from the bottom and side of solar still basin. The acrylic material has been selected due to its low thermal conductivity and high waterresistant nature. The still is designed for the maximum water depth of $10 \mathrm{~cm}$. Glass of $3.5 \mathrm{~mm}$ thickness used as the condensing cover, which is inclined at an angle of $30^{\circ}$. The condensing cover inclination is equal to the latitude of Sultanpur to receive maximum radiation from the sun. The basin of the still is painted black to enhance the capacity of the basin to receive the maximum solar radiation. A V-shaped trough of length $1.02 \mathrm{~m}$ is provided below the condensing cover to collect the condensed water from the glass surface. M-seal and putty were used to make still airtight and prevent water leakage.

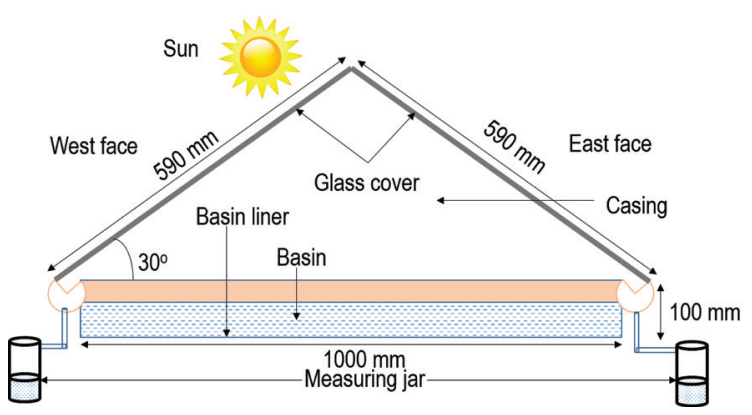

Fig. 1. A schematic diagram of solar still

\subsection{Experimental Measurements}

The experiments were performed in March and April 2016. The solar still was placed in the eastwest orientation for the experiments. Seven digital temperature sensors were used to record the temperature reading at the different locations of solar still. Global solar radiation, ambient temperature, and wind speed data were taken from the solar radiation 
resource assessment (SRRA) station installed at the KNIT, Sultanpur, India. A digital anemometer was used for measuring the wind velocity. The temperature readings were recorded at a one-hour interval. The experiments were carried out for different water depths, of which $2 \mathrm{~cm}, 3 \mathrm{~cm}, 4 \mathrm{~cm}$, and $5 \mathrm{~cm}$ are presented in this study.

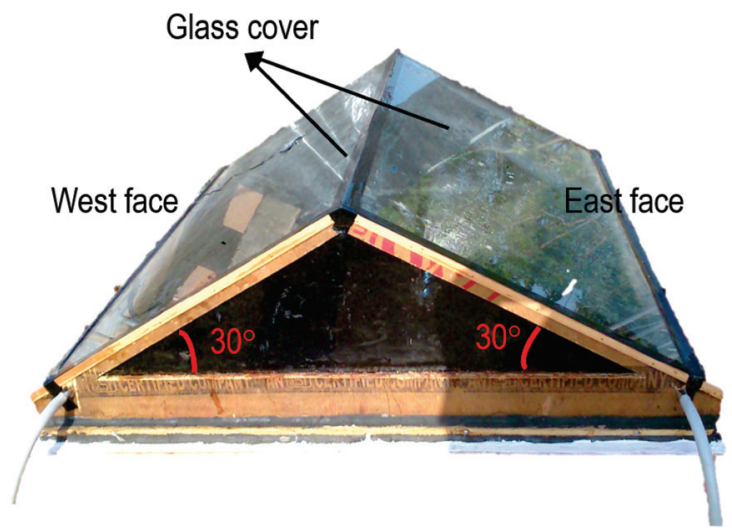

Fig. 2. Experimental setup of solar still

\subsection{Error Analysis of Experimental Measurements}

The errors associated with the different measuring instruments (solarimeter, digital thermometer, digital anemometer, and measuring jar) have been calculated based on the least count and the least value measured from that instrument during the experimentation. The minimum error is the ratio of the least value that an instrument can measure to the least value measured from that instrument. Table 1 shows the error percentages associated with the different measuring instruments.

Table 1. List of measuring devices and their accuracy and error

\begin{tabular}{lccc}
\hline Instrument & Range & Accuracy & Error [\%] \\
\hline Solarimeter & $0 \mathrm{~W} / \mathrm{m}^{2}$ to $2500 \mathrm{~W} / \mathrm{m}^{2}$ & $\pm 1 \mathrm{~W} / \mathrm{m}^{2}$ & 0.707 \\
\hline Thermometer & $-50^{\circ} \mathrm{C}$ to $150^{\circ} \mathrm{C}$ & $\pm 0.1^{\circ} \mathrm{C}$ & 0.37 \\
\hline Anemometer & $0 \mathrm{~m} / \mathrm{s}$ to $15 \mathrm{~m} / \mathrm{s}$ & $\pm 0.1 \mathrm{~m} / \mathrm{s}$ & 9.17 \\
\hline Measuring jar & $0 \mathrm{ml}$ to $1500 \mathrm{ml}$ & $\pm 1 \mathrm{ml}$ & 10 \\
\hline
\end{tabular}

\section{THERMAL CALCULATION FOR THE MODEL}

\subsection{Mathematical Model for Heat Transfer in Solar Still}

The heat transfer can be classified into two categories: internal and external heat transfer in a solar distillation system. The different heat interactions in the solar distillation unit are explained below.

\subsubsection{Internal Heat Transfer}

The internal heat transfer is the heat transfer between basin water and glass cover by convection, evaporation, and radiation.

\subsubsection{Convective Heat Transfer}

The heat transfer is taking place across the air, which is inside the solar still. As the system is airtight, there is no external velocity provided to the inside air to cause heat transfer. The air is humid because of vapour evaporating from the water surface; the heat transfer is due to the buoyancy only, meaning that free convection heat transfer occurs inside the still casing. The rate of convective heat transfer $\left(\dot{q}_{c w}\right)$ from the water surface to condensing glass cover is given by:

$$
\dot{q}_{c w}=h_{c w}\left(T_{w}-T_{g}\right) .
$$

The convective heat transfer coefficient depends on the operating temperature range of still and physical properties of the fluid at this operating temperature, condensing cover geometry and flow characteristics of the fluid. Dunkle [25] developed an equation for evaluation of the internal heat transfer coefficient:

$$
h_{c w}=0.0884\left(\Delta T^{*}\right)^{\frac{1}{3}}
$$

where $\Delta T^{*}=\left[\left(T_{w}-T_{g}\right)+\frac{\left(P_{w}-P_{g}\right)\left(T_{w}+273.15\right)}{268.9 \times 10^{3}-P_{w}}\right]$.

\subsubsection{Evaporative Heat Transfers}

The evaporative heat transfer occurs between the water surface and the inner glass surface of the DSSS.

The rate of evaporative heat transfer $\left(\dot{q}_{e w}\right)$ from the water surface to glass cover surface is given by:

$$
\dot{q}_{e w}=h_{e w}\left(T_{w}-T_{g}\right),
$$

and the evaporative heat transfer from the water surface to the glass surface is given by:

$$
\dot{q}_{e w}=0.0162 \times h_{c w}\left(P_{w}-P_{g}\right) .
$$

The above equation can be rearranged as:

$$
\dot{q}_{e w}=16.273 \times 10^{-3} h_{c w} \frac{\left(P_{w}-P_{g}\right)}{\left(T_{w}-T_{g}\right)}\left(T_{w}-T_{g}\right),
$$

where $h_{e w}=16.273 \times 10^{-3} h_{c w} \frac{\left(P_{w}-P_{g}\right)}{\left(T_{w}-T_{g}\right)}$, 
where $P_{w}$ and $P_{g}$ are partial saturation pressures $\left[\mathrm{W} / \mathrm{m}^{2}\right]$ and given by [26]:

$$
\begin{aligned}
& P_{g}=\exp \left[25.317-\frac{5144}{T_{g i}+273.15}\right], \\
& P_{w}=\exp \left[25.317-\frac{5144}{T_{w}+273.15}\right] .
\end{aligned}
$$

\subsubsection{Radiative Heat Transfer Coefficient}

The rate of radiative heat transfer $\left(\dot{q}_{r w}\right)$ from the water surface to glass cover for these infinite parallel surfaces is given by:

$$
\dot{q}_{r w}=\varepsilon_{e f f} \sigma\left[\left(T_{w}+273.15\right)^{4}-\left(T_{g}+273.15\right)^{4}\right] .
$$

The rate of radiative heat transfer is also given by:

$$
\dot{q}_{r w}=h_{r w}\left(T_{w}-T_{g}\right) .
$$

The $\left(h_{r w}\right)$ is the radiative heat transfer coefficient from the water surface to the glass cover and is given by (by comparing Eqs. (8) and (9)):

$$
\begin{aligned}
h_{r w} & =\varepsilon_{e f f} \sigma\left[\left(T_{w}+273.15\right)^{2}+\left(T_{g}+273.15\right)^{2}\right] \\
& \times\left[T_{w}+T_{g}+546.30\right] .
\end{aligned}
$$

where $e_{f f}$ is effective emissivity of water and glass surface, $\sigma$ Stefan-Boltzmann constant $\left(5.67 \times 10^{-8}\right.$ $\left.\mathrm{W} /\left(\mathrm{m}^{2} \mathrm{~K}^{4}\right)\right)$.

\subsubsection{External Heat Transfers}

The external heat transfer is primarily governed by conduction, convection, and radiation process, which are independent of each other. These heat transfers occur outside the solar distiller, from the glass cover and the bottom and side insulation.

\subsubsection{Top Loss Coefficient}

Due to the small thickness of the glass cover, the temperature of the glass may be assumed to be uniform. The external rate of heat transfer radiation $\left(\dot{q}_{r g}\right)$, convection $\left(\dot{q}_{c g}\right)$ and total heat $\left(\dot{q}_{t g}\right)$ losses from the glass to the ambient surroundings are expressed as:

$$
\begin{gathered}
\dot{q}_{t g}=\dot{q}_{r g}+\dot{q}_{c g}, \\
\dot{q}_{r g}=\sigma \varepsilon_{g}\left[\left(T_{g}+273.15\right)^{4}-\left(T_{s k y}+273.15\right)^{4}\right],
\end{gathered}
$$

$$
\dot{q}_{r g}=h_{r g}\left(T_{g}-T_{a}\right) .
$$

Comparing the above Eqs. (12) and (13), we obtain:

$$
h_{r g}=\frac{\varepsilon_{g} \sigma\left[\left(T_{g}+273.15\right)^{4}-\left(T_{s k y}+273.15\right)^{4}\right]}{\left(T_{g}-T_{a}\right)},
$$

where $T_{s k y}=T_{a}-6$ [27], $\varepsilon_{g}$ emissivity of the glass surface. The ambient emissivity is assumed to be 1 , as it behaves as a black body [8]. (In case of clear and cloudy sky, the difference between ambient temperature and effective sky temperature was assumed to be $6{ }^{\circ} \mathrm{C}$ ) and the rate of convective heat transfer from the glass surface to ambient is given by:

$$
\dot{q}_{c g}=h_{c g}\left(T_{g}-T_{a}\right) .
$$

On substituting the value of $\left(\dot{q}_{r g}\right)$ and $\left(\dot{q}_{c g}\right)$ in Eq. (11), we obtain:

$$
\dot{q}_{t g}=h_{t g}\left(T_{g}-T_{a}\right),
$$

where $h_{t g}=h_{r g}+h_{c g}$.

The expression for $\left(h_{t g}\right)$ and $\left(h_{c g}\right)$ is given by Watmuff and Charters [27]:

$$
\begin{gathered}
h_{t g}=5.7+3.8 \mathrm{~V}, \\
h_{c g}=2.8+3 \mathrm{~V},
\end{gathered}
$$

where $V$ is wind velocity [m/s], $h_{t g}$ is, $h_{r g}$ and $h_{c g}$ total, radiative, and convective heat transfer coefficient $\left[\mathrm{W} / \mathrm{m}^{2}\right]$ from the top glass surface, respectively.

\subsubsection{Bottom and Side Loss Coefficient}

Heat is also lost from the water in the basin to the ambient through the insulation, subsequently by convection and radiation from the bottom or side surface of the basin. The bottom loss coefficient $\left(U_{b}\right)$ can be written as:

$$
U_{b}=\left[\frac{1}{h_{w}}+\frac{1}{h_{b}}\right]^{-1} .
$$

The side loss coefficient $\left(U_{e}\right)$ can be expressed as:

$$
U_{e}=\frac{U_{b} A_{S S}}{A_{S}},
$$

where $A_{S S}$ is a sidewall surface area $\left[\mathrm{m}^{2}\right]$ in contact with basin water and $A_{S}$ area of the basin of the distiller $\left[\mathrm{m}^{2}\right] . A_{S S}$ is very small in comparison to $A_{S}$, for small water depth. Therefore, it can be neglected. 
The rate of heat loss per $\mathrm{m}^{2}$ from the basin liner to ambient can be written as:

$$
\dot{q}=h_{b}\left(T_{w}-T_{a}\right),
$$

where $h_{b}=\left[\frac{t_{i}}{K_{i}}+\frac{1}{h_{c b}+h_{r b}}\right]^{-1}$, where $h_{w}$ and $h_{b}$ are convective and overall heat transfer coefficient from basin liner to ambient through the bottom, $t_{i}$ thickness, $K_{i}$ thermal conductivity of the insulation material at the bottom, $h_{c b}$ and $h_{r b}$ convective and radiative heat transfer coefficient basin liner to ambient through the bottom.

\subsubsection{Determination of Distillate Output}

The hourly distillate output per $\mathrm{m}^{2}$ from the solar still can be obtained as:

$$
m_{e w}=\frac{\dot{q}_{e w}}{L} 3600, \text { or } m_{e w}=\frac{h_{e w}\left(T_{w}-T_{g}\right)}{L} 3600,
$$

where $L$ is latent heat of vaporization $[\mathrm{J} / \mathrm{kg}$ ] for less than $70^{\circ}$ and given by [27]:

$$
\begin{aligned}
L= & 2.4935 \times 10^{6}\left[1-9.4779 \times 10^{-4} T\right. \\
& \left.+1.3132 \times 10^{-7} T^{2}-4.7974 \times 10^{-9} T^{3}\right],
\end{aligned}
$$

where temperatures are in ${ }^{\circ} \mathrm{C}$ and heat transfer coefficients are in $\mathrm{W} /\left(\mathrm{m}^{2} \mathrm{~K}\right)$. The heat transfers rate presented in the thermal modelling are in $\mathrm{W} / \mathrm{m}^{2}$. The subscripts $w, g, a$, and $i$ indicate the basin water, glass surface, ambient and insulation respectively.

\section{RESULTS AND DISCUSSIONS}

The present experimental work has been carried out for heat transfer analysis of the east-west orientation of DSSS for various basin water depths $(2 \mathrm{~cm}, 3 \mathrm{~cm}$, $4 \mathrm{~cm}$ and $5 \mathrm{~cm}$ ). The east-west orientation has been chosen because the still gives maximum yield for this orientation. The experimental measurements were recorded and accurately from 8:00 $\mathrm{h}$ to $17: 00 \mathrm{~h}$. The mathematical equations which are used in the thermal model have solved analytically. As the difference between basin water and glass cover increases, the rate of heat transfer, as well as the production from the DSSS increases.

\subsection{Variation of Basin Water Temperature with Basin Water Depth}

In Fig. 3, the variation of basin water temperature with the depth of basin water and wind velocity are represented. It can be seen that the basin water temperature for $2 \mathrm{~cm}$ water depth is higher compared to $3 \mathrm{~cm}, 4 \mathrm{~cm}$, and $5 \mathrm{~cm}$ water depths. This is because the basin water with $3 \mathrm{~cm}, 4 \mathrm{~cm}$ and $5 \mathrm{~cm}$ depths have high thermal inertia compared to $2 \mathrm{~cm}$ water depth. Therefore, the basin filled with $2 \mathrm{~cm}$ water depth will be heated faster than other water depths. During the experiments, it was found that the

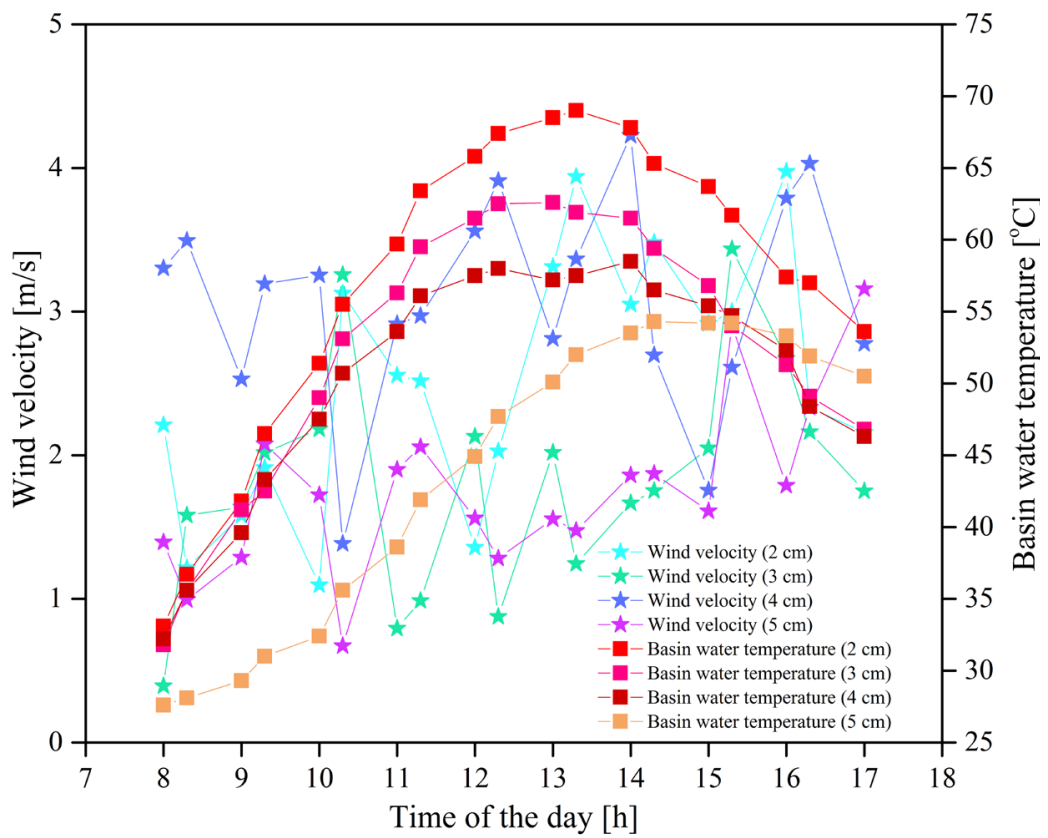

Fig. 3. Variation of basin water temperature with basin water depth and wind velocity 
maximum temperature for $2 \mathrm{~cm}, 3 \mathrm{~cm}, 4 \mathrm{~cm}$, and 5 cm depths are $69.0{ }^{\circ} \mathrm{C}, 62.6^{\circ} \mathrm{C}, 58.5^{\circ} \mathrm{C}$, and $54.4^{\circ} \mathrm{C}$, respectively, between 13:00 $\mathrm{h}$ and 14:30 $\mathrm{h}$. The peak starts shifted towards the right side as basin water depth increases from $2 \mathrm{~cm}$ to $5 \mathrm{~cm}$. This is because $5 \mathrm{~cm}$ water depth requires more time to be heated, due to the higher mass present in the basin. The basin water temperature was found to be maximum for $2 \mathrm{~cm}$ depth. The temperature decrease for $2 \mathrm{~cm}$ water depth was higher than other higher water depth after 14:00 $\mathrm{h}$ because of lower heat storage capacity. During the experimentation, the average wind velocity was found to vary between $2 \mathrm{~m} / \mathrm{s}$ to $3 \mathrm{~m} / \mathrm{s}$.

\subsection{Variation of Heat Transfer Coefficients with Basin Water Depth}

Figs. 4 to 6 show the variation of heat transfer coefficients (convective, evaporative, and radiative, respectively) for DSSS for the east and west glass. The curves are drawn for the positive value of temperature difference between basin water and glass cover surface $(\delta T)$. The yield from the solar still increases either increase in evaporation temperature or decrease in condensing surface temperature. In both cases, the $(\delta T)$ increases and the heat transfer rate increases.

Fig. 4 shows the variation of the convective heat transfer coefficient obtained from Eq. (2). The convective heat transfer rate is strongly dependent on the temperature difference between the water and glass cover surface. Fig. 4 shows that the average heat transfer coefficient for $2 \mathrm{~cm}$ water depth is maximum because of the higher temperature difference than higher water depths. This is because the lesser mass present in the basin with $2 \mathrm{~cm}$ depth requires less time to be heated. The maximum value of $h_{c w}$ were $2.48 \mathrm{~W} /\left(\mathrm{m}^{2} \mathrm{~K}\right), 2.25 \mathrm{~W} /\left(\mathrm{m}^{2} \mathrm{~K}\right), 2.21 \mathrm{~W} /\left(\mathrm{m}^{2} \mathrm{~K}\right)$, and $2.38 \mathrm{~W} /\left(\mathrm{m}^{2} \mathrm{~K}\right)$ for $2 \mathrm{~cm}, 3 \mathrm{~cm}, 4 \mathrm{~cm}$, and $5 \mathrm{~cm}$ depths, respectively. The heat transfer coefficients are higher than the results obtained in the experimental studies by Shukla and Rai [28]. The maximum heat transfer occurs around 13:00 to 14:00 h, while in the case with $5 \mathrm{~cm}$ depth, the maximum value of $h_{c w}$ occurs at 16:00 $\mathrm{h}$. This is because of the higher wind speed, which leads to faster cooling of the glass. Thus, the heat transfer of convection increases. The heat transfer coefficient is lower for $2 \mathrm{~cm}$ depth compared to 5 $\mathrm{cm}$ depth after 16:00 h. This is because of the higher thermal storage capacity of $5 \mathrm{~cm}$ water depth, which leads to higher basin water temperature.

Fig. 5 shows the variation of the evaporative heat transfer coefficient (calculated from Eq. (5)) with basin water depth for the experimental setup. It can be observed from Fig. 5 that the $h_{e w}$ is high for west glass because there is no direct sun heating of it in the morning, but as the evaporation starts and vapour start condensing on the west glass surface, the heat released during condensation heated the glass surface which leads the increase in the surface temperature of the glass. Thus, as the process continued, the temperature of west glass approaches saturation temperature, and due to this, condensation starts decreasing after 13:00 $\mathrm{h}, 13: 30 \mathrm{~h}$ and 14:00 h, and 14:30 h for $2 \mathrm{~cm}, 3 \mathrm{~cm}, 4$ $\mathrm{cm}$, and $5 \mathrm{~cm}$ water depths.

It is seen that from Figs. $4 \mathrm{a}$ and $5 \mathrm{a}$ that in the morning for $2 \mathrm{~cm}$ water depth, the rate of $h_{c w}$ and $h_{e w}$ is maximum for the west glass because basin water, as well as the east glass, is heated; therefore, the $\delta T$ is higher for the west glass as compared to the east glass. After 13:00 $\mathrm{h}$, the variation becomes closer for east and west glass because solar radiation does not directly fall on one glass only. This is also due to the higher basin water temperature as it absorbs solar energy since morning. However, in the case of higher water depths (i.e., $3 \mathrm{~cm}, 4 \mathrm{~cm}$, and $5 \mathrm{~cm}$ ), the east and west variation is almost eliminated because of the heating due to solar radiation and cooling due to wind. While $2 \mathrm{~cm}$ depth variation of heat transfer is faster than other depths, the wind velocity is higher with the $5 \mathrm{~cm}$ water depth; this is because of higher thermal energy storing capacity with the $5 \mathrm{~cm}$ depth consequent the slower cooling of the basin water. The $h_{c w}$ of east and west surfaces for the present solar still is higher for the period of 15:00 to 17:00, compared to Shukla and Rai [28]. This is because of the higher basin temperature and low thermal conductivity of acrylic material of solar still, which reduces the heat loss of the basin water.

The average evaporative heat transfers were higher for $2 \mathrm{~cm}$ depth than other water depths $(3 \mathrm{~cm}$, $4 \mathrm{~cm}$, and $5 \mathrm{~cm}$ ). Therefore, the yield in the case of 2 $\mathrm{cm}$ water depth is maximum as the evaporation rate is the main driving parameter for the production from the solar still. From Fig. 5, the $h_{e w}$ starts decreasing at a faster rate for $2 \mathrm{~cm}$ depth compared to other water depths. This is not only because of low heat-storing capacity for $2 \mathrm{~cm}$ water depth but also because of the lower heating rate for the other higher depths; thus, from the evening, the production rate starts decreasing faster for lower and nocturnal production is more for higher depths.

The maximum value of $h_{e w}$ is found to be $55.05 \mathrm{~W} /\left(\mathrm{m}^{2} \mathrm{~K}\right), 49.23 \mathrm{~W} /\left(\mathrm{m}^{2} \mathrm{~K}\right), 31.25 \mathrm{~W} /\left(\mathrm{m}^{2} \mathrm{~K}\right)$ and $31.80 \mathrm{~W} /\left(\mathrm{m}^{2} \mathrm{~K}\right)$ for $2 \mathrm{~cm}, 3 \mathrm{~cm}, 4 \mathrm{~cm}$ and $5 \mathrm{~cm}$ water depths. The peak of $h_{e w}$ shifted to the right as the mass in the basin starts increasing; this is due 

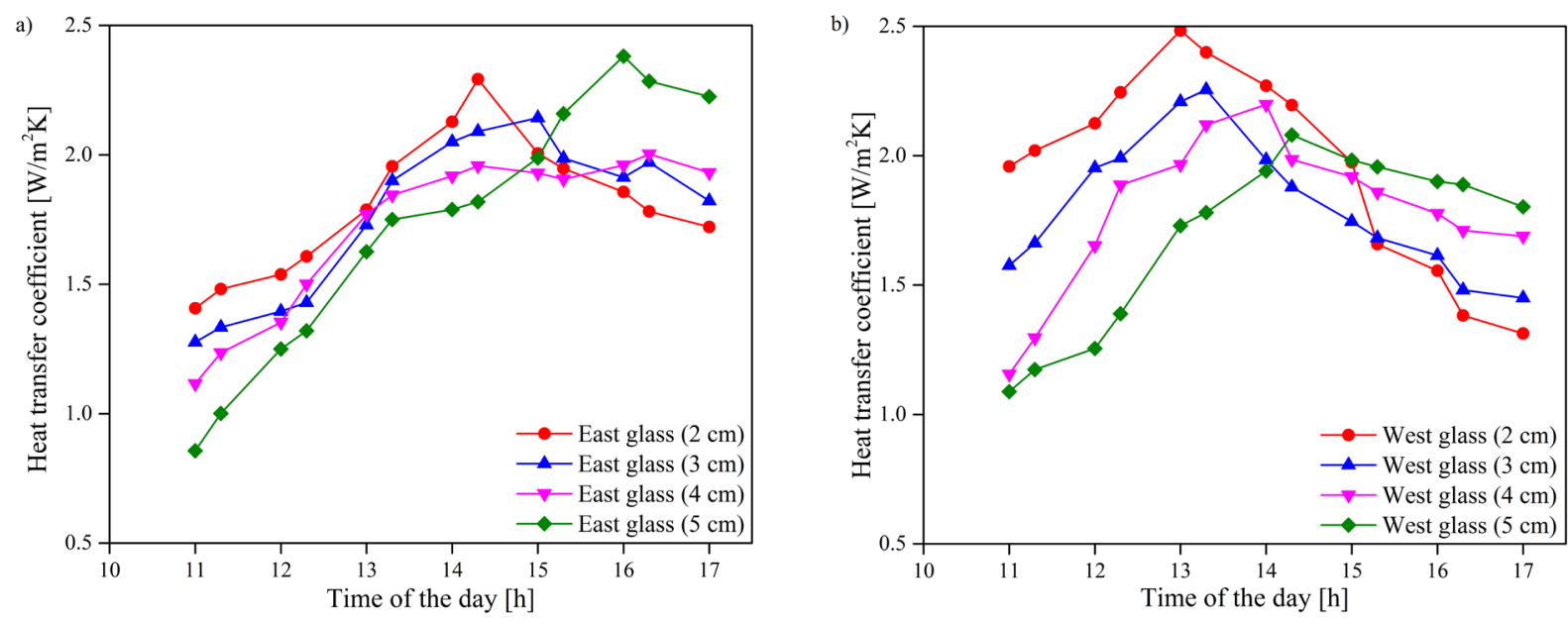

Fig. 4. Variation of the convective heat transfer coefficient with basin water depth for: a) east glass, and b) west glass
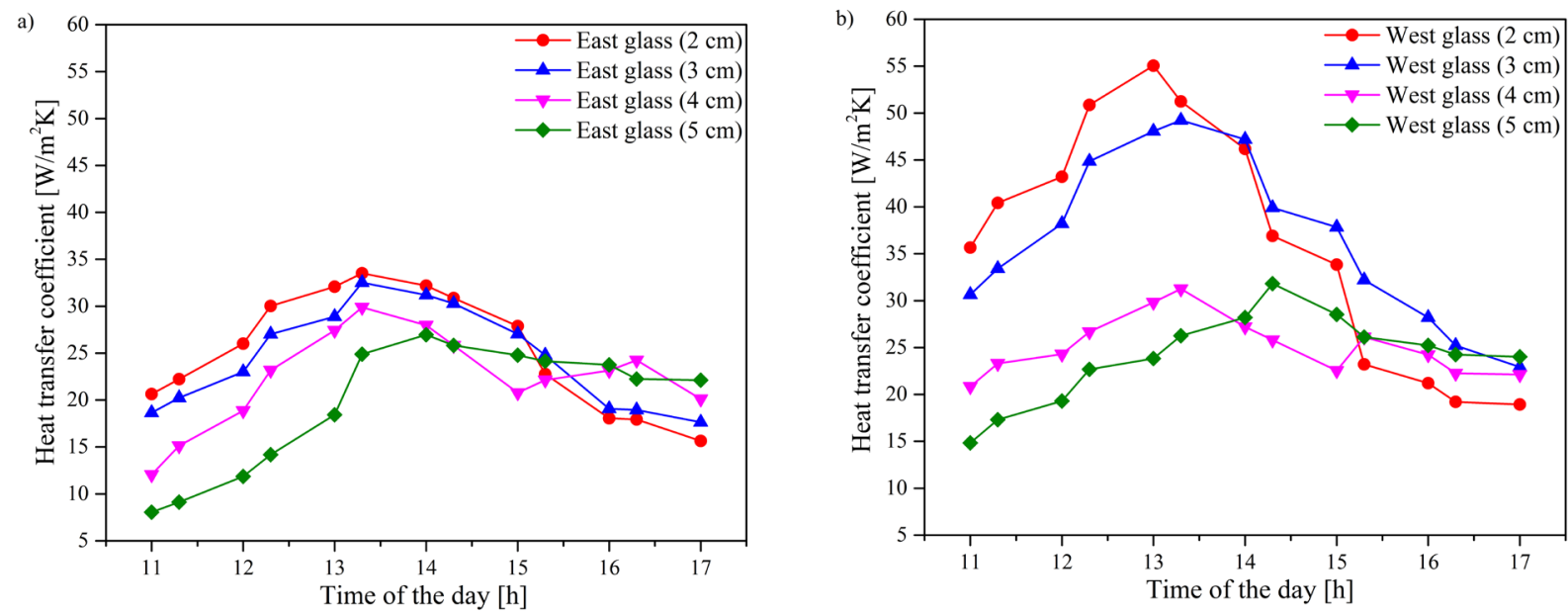

Fig. 5. Variation of evaporative heat transfer coefficient with basin water depth for a) east glass b) west glass
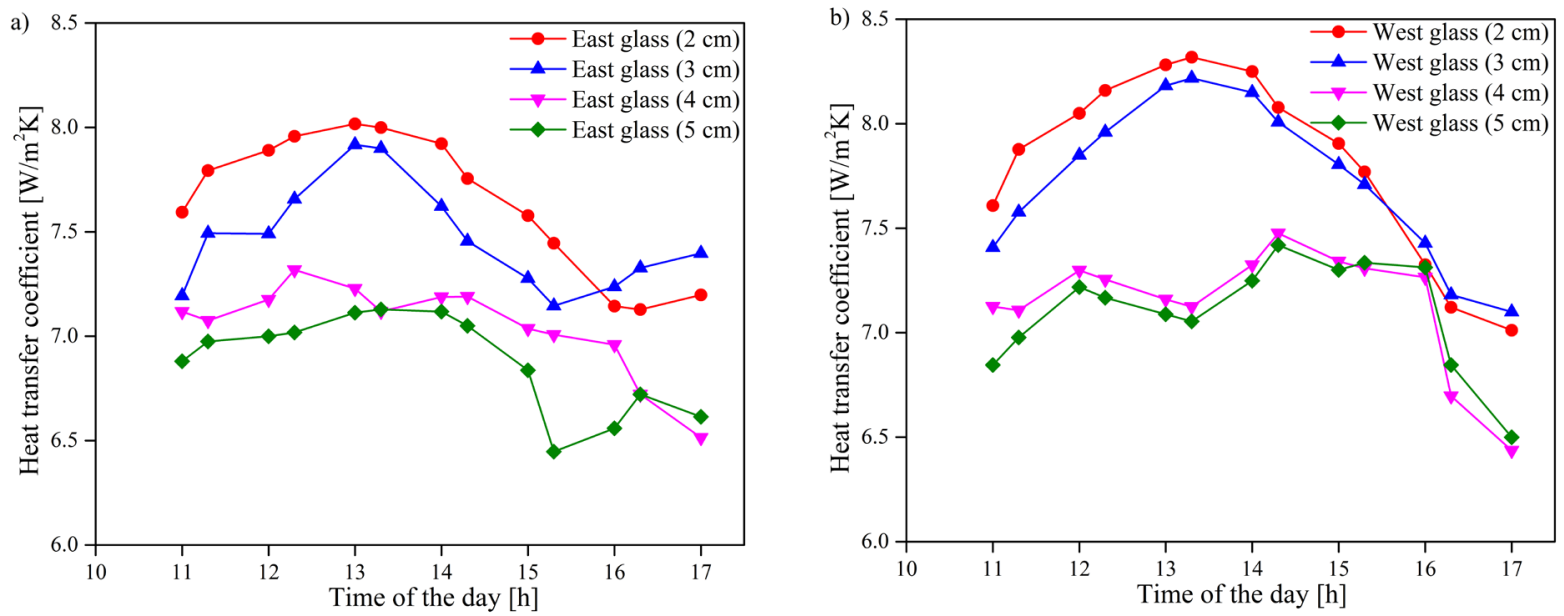

Fig. 6. Variation of radiative heat transfer coefficient with basin water depth for a) east glass b) west glass

to lower thermal inertia for $2 \mathrm{~cm}$ depths compared to others depth. The maximum value of $h_{c w}$ and $h_{e w}$ are found to be $2.48 \mathrm{~W} /\left(\mathrm{m}^{2} \mathrm{~K}\right)$ and $55.05 \mathrm{~W} /\left(\mathrm{m}^{2} \mathrm{~K}\right)$ for the west glass, respectively, for $2 \mathrm{~cm}$ depth. 
There are some fluctuations in heat transfer because of uncontrolled wind speed over the DSSS glass surfaces. From Fig. 5, it can be seen that the heat transfer coefficient increases for higher water depths. This is due to an increase in wind speed which leads to better evaporation as well as condensation. When the results are compared with those of Shukla and Rai [28], the maximum and average evaporative heat transfer coefficients are found to be higher in this study. This is due to the higher temperature difference obtained with the present experimental setup. This higher temperature difference is because of higher basin temperature also due to the insulating nature of acrylic.

Fig. 6 shows the variation of radiation heat transfer's coefficient (calculated from Eq. (8)) for
$2 \mathrm{~cm}, 3 \mathrm{~cm}, 4 \mathrm{~cm}$ and $5 \mathrm{~cm}$ water deptha for the experimental setup for the east and west glass of DSSS. The radiation heat transfer mainly depends on the basin water and glass surface temperature and the emissivity of basin water and glass surface. As the evaporation increases, the surface temperature of the glass surface increases due to the condensation of vapour on the glass surface. Therefore, the radiation heat transfer coefficient increases. The maximum heat transfer coefficients are found to be $8.32 \mathrm{~W} /\left(\mathrm{m}^{2} \mathrm{~K}\right)$, $8.21 \mathrm{~W} /\left(\mathrm{m}^{2} \mathrm{~K}\right), 7.47 \mathrm{~W} /\left(\mathrm{m}^{2} \mathrm{~K}\right)$ and $7.41 \mathrm{~W} /\left(\mathrm{m}^{2} \mathrm{~K}\right)$ for $2 \mathrm{~cm}, 3 \mathrm{~cm}, 4 \mathrm{~cm}$ and $5 \mathrm{~cm}$ water depths, respectively. Shukla and Rai [28] showed a lower radiative heat transfer coefficient than the present study did. This is because of the higher evaporation and condensation associated with the design of DSSS. In the present
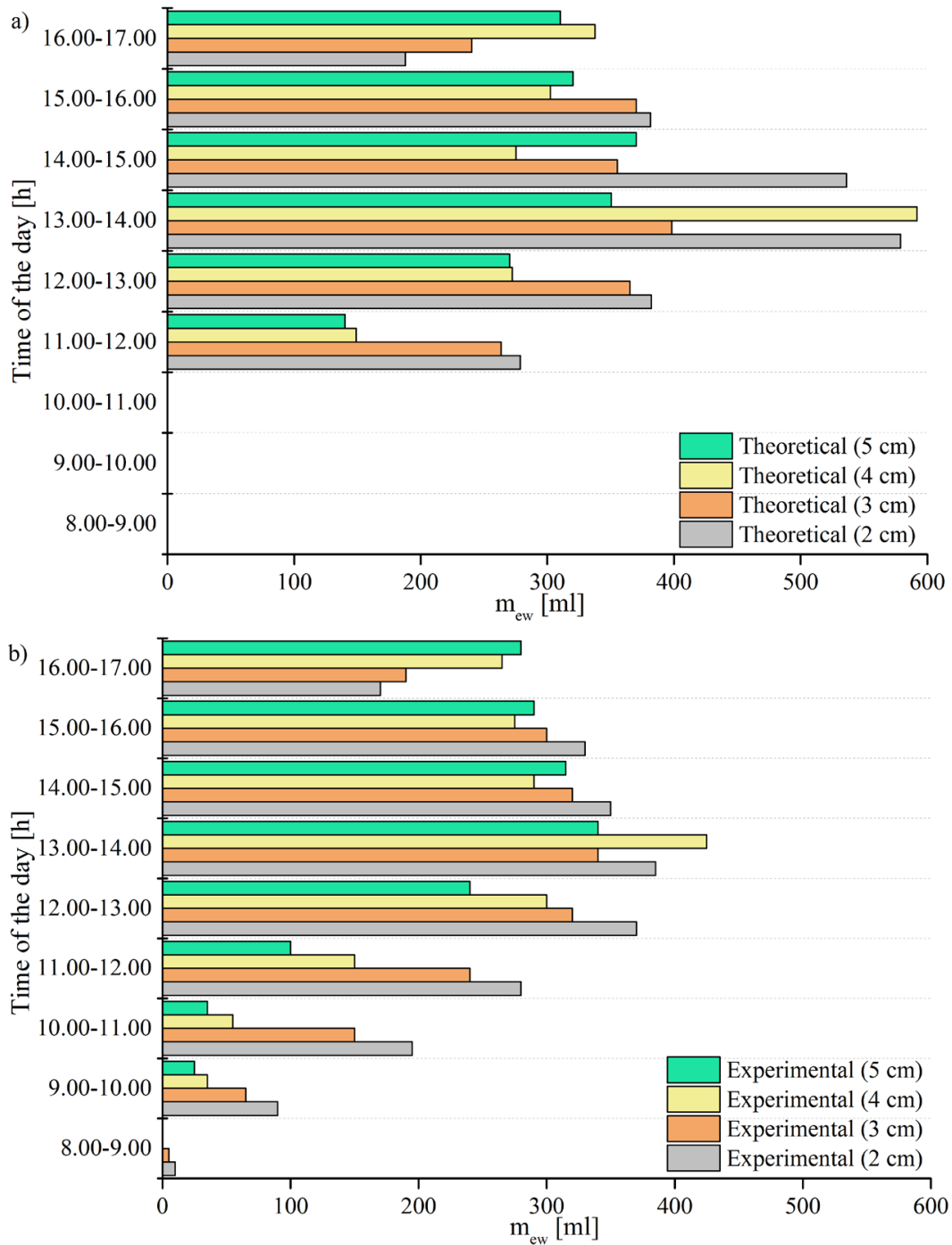

Fig. 7. Hourly yield from per $\mathrm{m}^{2}$ area of the solar still at $2 \mathrm{~cm}, 3 \mathrm{~cm}, 4 \mathrm{~cm}$ and $5 \mathrm{~cm}$ water depth; a) theoretical, and b) experimental 
study, the radiative heat transfer coefficient for $2 \mathrm{~cm}$ and $3 \mathrm{~cm}$ depth are higher because of the high basin temperature and higher evaporation associated with these depths, leading to increases in glass temperature as the $h_{r w}$ is the function of both glass and basin water temperature. It was also observed that the $h_{e w}$ (west surface) was much higher for $3 \mathrm{~cm}$ compared to $h_{r w}$, but the variation in $h_{r w}$ for $2 \mathrm{~cm}$ and $3 \mathrm{~cm}$ (Fig. 6b) is closer due to higher evaporation compensated by higher basin temperature for $2 \mathrm{~cm}$ depth.

Fig. 7 shows the theoretical (calculated from Eq. (17)) and experimental yield from the still for 2 $\mathrm{cm}, 3 \mathrm{~cm}, 4 \mathrm{~cm}$, and $5 \mathrm{~cm}$ water depths in the basin. The theoretical yield from the still is higher than the experimental yield, but sometimes it is lower than experimental because of the atmospheric condition like wind speed; due to this, the vapour is condensed rapidly, whereas the theoretical yield depends on the temperature difference between the glass and basin water; also. the data recorded are average data. The yield for $2 \mathrm{~cm}$ water depth is higher than $3 \mathrm{~cm}, 4 \mathrm{~cm}$. and $5 \mathrm{~cm}$ water depths. This proves that the yield is higher for a lower basin mass. After 15:00 h, it can be seen that the yield for $2 \mathrm{~cm}$ depth is decreasing at a faster rate compared to other higher depts. This is due to the heat-storing capacity of the basin mass. This proves that the evening and off-sun time production is higher for higher basin mass. Before the afternoon, the yield rate is higher for $2 \mathrm{~cm}$ depth because of the higher evaporation rate as compared to other water depths.

The wind has a positive effect on yield with higher depth compared to a lower depth. This is because the lesser depth $(2 \mathrm{~cm})$ of basin water's temperature decreases faster, which enhances the yield. While for higher depth $(4 \mathrm{~cm})$, this has a less negative effect due to the higher energy storing capability of water mass. It can be seen from Figs. 3 and $7 \mathrm{~b}$ that the yield is higher when wind speed increases. This is because of the higher temperature gradient between the basin water condensing glass cover for $4 \mathrm{~cm}$ compared to the $2 \mathrm{~cm}$ depth water depth. The yield from the still is higher for the $4 \mathrm{~cm}$ depth between 13:00 $\mathrm{h}$ and15:00 $\mathrm{h}$ not only because of the wind speed but also due to the higher water mass, which stores more thermal energy and release during this time period. From Fig. 7b, it can be seen that the rate of production increases for $2 \mathrm{~cm}$ as well as $4 \mathrm{~cm}$ depths at a very high rate. This is due to an increase in wind speed and the high solar radiation during this period.

\section{CONCLUSIONS}

The DSSS of acrylic with basin area $1 \mathrm{~m}^{2}$ with an inclination angle of $30^{\circ}$ was fabricated for the climatic condition of Sultanpur, Uttar Pradesh, India. Various experiments were performed on this setup to analyze the effect of parameters, including different depths (2 $\mathrm{cm}, 3 \mathrm{~cm}, 4 \mathrm{~cm}$ and $5 \mathrm{~cm}$ ), the wind velocity effect on the yield, and heat transfers. The experimental and theoretical yields have been compared. The following conclusions have been drawn from the present study.

1. Convective and evaporative heat transfers are the most critical parameter for a solar distillation unit. The maximum value of $h_{e w}\left(55.05 \mathrm{~W} /\left(\mathrm{m}^{2} \mathrm{~K}\right), 49.2\right.$ $\mathrm{W} /\left(\mathrm{m}^{2} \mathrm{~K}\right), 31.25 \mathrm{~W} /\left(\mathrm{m}^{2} \mathrm{~K}\right)$ and $\left.31.80 \mathrm{~W} /\left(\mathrm{m}^{2} \mathrm{~K}\right)\right)$ and $h_{c w}\left(2.48 \mathrm{~W} /\left(\mathrm{m}^{2} \mathrm{~K}\right), 2.25 \mathrm{~W} /\left(\mathrm{m}^{2} \mathrm{~K}\right), 2.19 \mathrm{~W} /\right.$ $\left(\mathrm{m}^{2} \mathrm{~K}\right)$ and $\left.2.38 \mathrm{~W} /\left(\mathrm{m}^{2} \mathrm{~K}\right)\right)$ was found for $2 \mathrm{~cm}, 3$ $\mathrm{cm}, 4 \mathrm{~cm}$, and $5 \mathrm{~cm}$ depths, respectively.

2. The radiative heat transfer coefficient is found to be a maximum of $8.39 \mathrm{~W} /\left(\mathrm{m}^{2} \mathrm{~K}\right)$ for $2 \mathrm{~cm}$ depth, and it increases as the rate of condensation increases on the glass surface.

3. The yield from the still increases as the basin water depth decreases because the lower basin water requires less time to come into steady-state, and due to this, the evaporation starts earlier.

4. On increasing the depth from $2 \mathrm{~cm}$ to $4 \mathrm{~cm}$, the yield decreases by $17.62 \%$. In comparison, it decreases by $25.45 \%$ when the water depth is $5 \mathrm{~cm}$. The maximum yield of $2.5 \mathrm{1} / \mathrm{m}^{2}$ per day is found for $2 \mathrm{~cm}$ water depth. The theoretical and experimental yield from solar still agreed with an error of $7.5 \%, 3.25 \%, 7.4 \%$ and $8.4 \%$ for $2 \mathrm{~cm}$, $3 \mathrm{~cm}, 4 \mathrm{~cm}$ and $5 \mathrm{~cm}$ water depths, respectively.

5. The afternoon production is higher for the higher basin mass because of the heat-storing capacity of basin mass.

6. During the initial time duration of still (i.e. $1 \mathrm{~h}$ to $2 \mathrm{~h}$ of operations), the rate of convective, evaporative, and radiative heat transfer coefficients is less. This is due to the slow heating of water mass in the basin because of the outer glass surface at a higher temperature than the lower surface.

7. The yield of DSSS increases as the wind speed increase because this leads to faster condensation at the glass surface. The higher basin mass temperature is less affected by the variation in wind velocity. 


\section{NOMENCLATURES}

$\dot{q}_{c w}$ rate of convective heat transfer from water to glass cover, $\left[\mathrm{W} / \mathrm{m}^{2}\right]$

$h_{c w}$ convective heat transfer coefficient from water to condensing cover, $\left[\mathrm{W} /\left(\mathrm{m}^{2} \mathrm{~K}\right)\right]$

$\dot{q}_{e w}$ rate of evaporative heat transfer from water to glass cover, $\left[\mathrm{W} / \mathrm{m}^{2}\right]$

$h_{e w}$ evaporative heat transfer coefficient, $\left[\mathrm{W} /\left(\mathrm{m}^{2} \mathrm{~K}\right)\right]$

$\dot{q}_{r w}$ rate of radiative heat transfer from water to glass cover, $\left[\mathrm{W} / \mathrm{m}^{2}\right]$

$h_{r w}$ radiative heat transfer coefficient, $\left[\mathrm{W} /\left(\mathrm{m}^{2} \mathrm{~K}\right)\right]$

$\varepsilon_{\text {eff }}$ effective emissivity of glass and water, [-]

$\varepsilon_{g} \quad$ emissivity of glass, [-]

$\varepsilon_{w}$ emissivity of water, [-]

$\rho$ Stefan Boltzmann constant, $\left[\mathrm{W} /\left(\mathrm{m}^{2} \mathrm{~K}^{4}\right)\right]$

$\dot{q}_{g}$ rate of total heat transfer from glass cover to ambient, $\left[\mathrm{W} / \mathrm{m}^{2}\right]$

$\dot{q}_{r g}$ rate of radiative heat transfer from glass cover to ambient, $\left[\mathrm{W} / \mathrm{m}^{2}\right]$

$h_{r g}$ radiative heat transfer coefficient from glass cover to ambient, $\left[\mathrm{W} /\left(\mathrm{m}^{2} \mathrm{~K}\right)\right]$

$\dot{q}_{c g}$ rate of convective heat transfer from glass cover to ambient, $\left[\mathrm{W} / \mathrm{m}^{2}\right]$

$h_{c g}$ convective heat transfer coefficient from glass surface to ambient, $\left[\mathrm{W} /\left(\mathrm{m}^{2} \mathrm{~K}\right)\right]$

$\dot{q}_{t g}$ rate of total heat transfer from glass cover to ambient, $\left[\mathrm{W} / \mathrm{m}^{2}\right]$

$h_{t g}$ total heat transfer coefficient from glass surface to ambient, $\left[\mathrm{W} /\left(\mathrm{m}^{2} \mathrm{~K}\right)\right]$

$U_{b}$ bottom heat loss coefficient, $\left[\mathrm{W} /\left(\mathrm{m}^{2} \mathrm{~K}\right)\right]$

$U_{e}$ side heat loss coefficient, $\left[\mathrm{W} /\left(\mathrm{m}^{2} \mathrm{~K}\right)\right]$

$h_{w}$ convective heat transfer coefficient from basin liner to water, $\left[\mathrm{W} /\left(\mathrm{m}^{2} \mathrm{~K}\right)\right]$

$h_{c b}$ convective heat transfer coefficient from basin liner to ambient, $\left[\mathrm{W} /\left(\mathrm{m}^{2} \mathrm{~K}\right)\right]$

$h_{r b}$ radiative heat transfer coefficient from basin liner to ambient, $\left[\mathrm{W} /\left(\mathrm{m}^{2} \mathrm{~K}\right)\right]$

$h_{b}$ overall heat transfer coefficient from basin liner to ambient through bottom, $\left[\mathrm{W} /\left(\mathrm{m}^{2} \mathrm{~K}\right)\right]$

$T_{g}$ temperature of condensing cover, $\left[{ }^{\circ} \mathrm{C}\right]$

$T_{b}$ temperature of basin, $\left[{ }^{\circ} \mathrm{C}\right]$

$T_{w}$ water temperature, $\left[{ }^{\circ} \mathrm{C}\right]$

$T$ water vapour temperature, $\left[{ }^{\circ} \mathrm{C}\right]$

$T_{\text {sky }}$ temperature of sky, $\left[{ }^{\circ} \mathrm{C}\right]$

$T_{a}$ ambient temperature, $\left[{ }^{\circ} \mathrm{C}\right]$

$V$ wind velocity, $[\mathrm{m} / \mathrm{s}]$

$t_{i} \quad$ thickness of insulation material, [m]

$K_{i}$ thermal conductivity of insulation material, $[\mathrm{W} /(\mathrm{m} \cdot \mathrm{K})]$

$P_{w}$ partial vapour pressure at water temperature, $\left[\mathrm{N} / \mathrm{m}^{2}\right]$
$P_{g}$ partial vapour pressure at glass temperature, $\left[\mathrm{N} / \mathrm{m}^{2}\right]$

$m_{e w}$ distillate output, $\left[\mathrm{kg} / \mathrm{m}^{2} / \mathrm{h}\right]$

$L \quad$ latent heat of vaporization, $[\mathrm{J} / \mathrm{kg}]$

$h_{b}$ overall heat transfer coefficient from basin liner to ambient through bottom insulation, $\left[\mathrm{W} /\left(\mathrm{m}^{2} \mathrm{~K}\right)\right]$ $A S S$ surface area in contact with water, $\left[\mathrm{m}^{2}\right]$ $A S$ area of the basin of the distiller, $\left[\mathrm{m}^{2}\right]$

\section{REFERENCES}

[1] Kannan, N., Vakeesan, D. (2016). Solar energy for future world: A review. Renewable and Sustainable Energy Reviews. vol. 62, p. 1092-105, D0l:10.1016/j.rser.2016.05.022.

[2] Patel, R.V.P., Kumar, A. (2017). Experimental investigation of double slope solar still for the climatic condition of Sultanpur. International Journal of Engineering and Technology, vol. 9, no. 6, p. 4019-4033, D0I:10.21817/ijet/2017/v9i6/170906309.

[3] Patel, R.V., Bharti, K., Singh, G., Mittal, G., Singh, D.B., Yadav, A. (2021). Comparative investigation of double slope solar still by incorporating different types of collectors: A mini review. Materials Today: Proceedings, vol. 38, p. 300-304, D0l:10.1016/j.matpr.2020.07.338.

[4] Misra, S., Patel, R.V., Kumar, A., Yadav, A., Patel, V. (2021) Effect of Climatic Conditions and Water Depth on Yield of Single Slope Solar Still. Current Advances in Mechanical Engineering: Select Proceedings of ICRAMERD 2020, p. 137147, DOI:10.1007/978-981-33-4795-3_14.

[5] Sharshir, S.W., Ellakany, Y.M., Algazzar, A.M., Elsheikh, A.H., Elkadeem, M.R., Edreis, E.M.A., Waly, A.S., Sathyamurthy, R., Panchal, H., Elashry, M.S. (2019). A mini review of techniques used to improve the tubular solar still performance for solar water desalination. Process Safety and Environmental Protection, vol. 124, p. 204-212, D0I:10.1016/j. psep.2019.02.020.

[6] Tiwari, A.Kr., Tiwari, G.N. (2006). Effect of water depths on heat and mass transfer in a passive solar still: in summer climatic condition. Desalination, vol. 195, no. 1-3, p. 78-94, D0l:10.1016/j.desal.2005.11.014.

[7] Zarasvand Asadi, R., Suja, F., Ruslan, M.H., Jalil, N.A. (2013). The application of a solar still in domestic and industrial wastewater treatment. Solar Energy, vol. 93, no. 63-71, D0I:10.1016/j.solener.2013.03.024.

[8] Ali, M.T., Fath, H.E.S., Armstrong, P.R. (2011). A comprehensive techno-economical review of indirect solar desalination. Renewable and Sustainable Energy Reviews, vol. 15, no. 8, p. 41874199, DOI:10.1016/j.rser.2011.05.012.

[9] Dev, R., Abdul-Wahab, S.A., Tiwari, G.N. (2011). Performance study of the inverted absorber solar still with water depth and total dissolved solid. Applied Energy, vol. 88, no. 1, p.252264, DOI:10.1016/j.apenergy.2010.08.001.

[10] Phadatare, M.K., Verma, S.K. (2007). Influence of water depth on internal heat and mass transfer in a plastic solar still. Desalination, vol. 217, no. 1-3, p. 267-275, D0l:10.1016/j. desal.2007.03.006.

[11] Tripathi, R., Tiwari, G.N. (2006). Thermal modeling of passive and active solar stills for different depths of water by using the 
concept of solar fraction. Solar Energy, vol. 80, p. 956-967, DOI:10.1016/j.solener.2005.08.002.

[12] Feilizadeh, M., Karimi Estahbanati, M.R., Ahsan, A., Jafarpur, K., Mersaghian, A. (2016). Effects of water and basin depths in single basin solar stills: An experimental and theoretical study. Energy Conversion and Management, vol. 122, p. 174181, D0I:10.1016/j.enconman.2016.05.048.

[13] El-Sebaii, A.A. (2011). On effect of wind speed on passive solar still performance based on inner/outer surface temperatures of the glass cover. Energy, vol. 36, no. 8, p. 4943-4949. DOl:10.1016/j.energy.2011.05.038.

[14] El-Sebaii A.A. (2004). Effect of wind speed on active and passive solar stills. Energy Conversion and Management, vol. 45, no. $7-8$, p. 1187-1204, D0l:10.1016/j. enconman.2003.09.036.

[15] Danish, S.N., El-Leathy, A., Alata, M., Al-Ansary, H. (2019). Enhancing solar still performance using vacuum pump and geothermal energy. Energies, vol. 12, no. 3, art. ID 539, DOl:10.3390/en12030539.

[16] Thalib, M.M., Manokar, A.M., Essa, F.A., Vasimalai, N., Sathyamurthy, R., Garcia Marquez, F.P. (2020). Comparative study of tubular solar stills with phase change material and nano-enhanced phase change material. Energies, vol. 13, no. 15, art. ID. 3989, D0I:10.3390/en13153989.

[17] Singh, R., Kumar, A., Yadav, A. (2019). Performance analysis of the solar photovoltaic thermal system using phase change material. IOP Conference Series: Materials Science and Engineering, vol. 577, art. ID 012166, D0I:10.1088/1757899X/577/1/012166.

[18] Safaei, M.R., Goshayeshi, H.R., Chaer, I.. (2019). Solar still efficiency enhancement by using graphene oxide/ paraffin nano-PCM. Energies, vol. 12, no. 10, art. ID 2002, DOI:10.3390/en12102002.

[19] Nazari, S., Safarzadeh, H., Bahiraei, M. (2019). Performance improvement of a single slope solar still by employing thermoelectric cooling channel and copper oxide nanofluid: An experimental study. Journal of Cleaner Production, vol. 208, p. 1041-1052, D0I:10.1016/j.jclepro.2018.10.194.

[20] El-Sebaey, M.S., Ellman, A., Hegazy, A., Ghonim, T. (2020). Experimental analysis and CFD modeling for conventional basin-type solar still. Energies, vol. 13, no. 21., art. ID 5734, DOI:10.3390/en13215734.

[21] Rahbar, N., Esfahani, J.A. (2013). Productivity estimation of a single-slope solar still: Theoretical and numerical analysis. Energy, vol. 49, no. 289-297, D0l:10.1016/j. energy.2012.10.023.

[22] Setoodeh, N., Rahimi, R., Ameri, A. (2011). Modeling and determination of heat transfer coefficient in a basin solar still using CFD. Desalination, vol. 268, no. 1-3, 103-110, DOl:10.1016/j.desal.2010.10.004.

[23] Madhlopa, A. (2014). Modelling radiative heat transfer inside a basin type solar still. Applied Thermal Engineering, vol. 73, no. 1, p. 707-711, D0l:10.1016/j.applthermaleng.2014.07.065.

[24] Keshtkar, M., Eslami, M., Jafarpur, K. (2020). A novel procedure for transient CFD modeling of basin solar stills: Coupling of species and energy equations. Desalination, vol. 481, art. ID 114350, D0I:10.1016/j.desal.2020.114350.

[25] Dunkle, R.V. (1961). Solar wter distillation: the roof type still and a multiple effect diffusion still. International Developments in Heat Transfer, ASME, Proceeding of International Heat Transfer, part V, p. 895.

[26] Fernández, J., Chargoy, N. (1990). Multi-stage, indirectly heated solar still. Solar Energy, vol. 44, no. 4, p. 215-223, DOI:10.1016/0038-092X(90)90150-B.

[27] Watmuff, J.H., Charters, W.W.S., Proctor, D. (1977). Solar and wind induced external coefficients-solar collectors. CMES, p. 56.

[28] Shukla, K.S., Rai, A.K. (2008). Analytical thermal modeling of double slope solar still by using inner glass cover temperature. Thermal Science, vol. 12, no. 3, p. 139-152, D0l:10.2298/ TSCI0803139S. 